of the wing, where it attains internal margin, and spreading across the hind part of the thorax. It is darker shaded, somewhat brownish anteriorly. Collar dead black. The black lines are indicated on the gray costal margin. Orbicular a minute dot. Reniform strongly indicated, sur rounded with the pale shading of costal margin. T. p. line continuous, reddish brown where it crosses the gray margin, and here angulate, black below and strongly marked, a little dentate. Subterminal line followed by an interrupted reddish brown shading. Terminal line black, festooned, followed by a pale thread-like line at base of fringes, which latter are blackish. The denticulate black t. p. line continued across hind wings, which agree with the primaries. Over the middle of the wings are two or three blackish shade lines representing the median shade and t. a. line. Beneath a little paler, with small discal marks, white centered. Feet dotted with white; abdomen blackish. Expanse 3. mil. Hab. Bastrop Co. (O. Meske).

This species seems to be allied to Selenis lanipes Guen., of unknown locality. It appears to differ decidedly in color, the continuous black transverse posterior line, and the absence of the multitude of parallel, denticulate, unequal violet gray, reddish and black lines, crossing the wings in lanipes. There is also the absence of any sexual character in the clothing of the hind tarsi, unless I have made a mistake in my determination, which, after re-examining both hind wings, I think is not the case. The "ligne coudeé" is, instead of being continuous and evenly strong as in monotropa, "indiqueé par des traits noirs plus épais, fondus inferieurement," in lanipes. Gueneés figure represents a similarly sized but much higher colored insect than the one I describe, and I do not think there is any reasonable doubt that they are different species.

NOTES ON THE OCCURRENCE OF ARGYNNIS IDALIA DRURY.

BY H. H. LYMAN, MONTREAL, P. Q.

Mr. W. H. Edwards, in his article on Argynnis myrina, published on page 189 of Vol. vii, of the CANAdian EnTonologist, says that in all the species of butterflies which he has made observations on, except Apatura clyton, the females emerge as early as the males, and in the course 
of the same article he mentions having "bred from the egg four of our larger species of Argynnis, viz., diana, cybele, aphrodite and idalia."

Does $A$. idalia occur in Mr. Edwards' neighborhood, and to what extent has he obtained the imagines from eggs? The only other reference by bim in the CAN. ENT. to A. idalia, that I can find, is on page $\mathrm{r}_{5} \mathrm{I}$ of Vol. vii, where he states that Mr. G. M. Dodge had sent him several eggs of this species from Nebraska, and that he had succeeded in carrying a few of the larva through the winter and one past the fifth moult, but that this one died before chrysalis.

Though I do not presume to question the statements of so distinguished an Entomologist as Mr. Edwards, I thought that I would give my experience with regard to this butterfly, and I should like to know whether any one else has had a similar experience.

I may state that I have collected for eight successive summers on Cape Elizabeth, in the vicinity of Portland, Me., where this butterfly occurs every season, and though generally not common, is sometimes somewhat plentiful.

My experience has been that, though I might find a stray female almost as early as the males, the great majority of females did not appear for a week or ten days after the males. It is only within the last three years that I have kept an entomological diary and numbered my specimens, so that I cannot give any figures with regard to those taken or observed before 1873 , but $I$ remember noticing the fact previous to that date; however, this species was tolerably abundant during the past season $(\mathrm{I} 875)$, and I can give some dates in support of what I say.

By referring to my journal for this year, I find that I took the first $\hat{\delta}$ of the season on zoth July, three more on July 24 th, on which day I also caught one $q$, and from July zoth to 3 Ist I took altogether Io $\hat{\delta}$ and I $q$. Unfortunately the weather during the first half of August was very
bad, almost every day being foggy or rainy, or both, so that I an unable
to state when the femates emerged. to state when the females emerged.

On one partially fine day, Aug. 9th, I obtained another $\delta$, and during the last half of August worn females were obtainable, but they were too
poor for cabinet specimens.

In 1874 this species was very scarce, and I only obtained two specimens, $\delta$ on July 28 th, and a badly rubbed $f$ on Sept. 3 rd.

In 1873 it was also scarce and I only took two $\hat{\delta}$, one on July $x 6$ th and another on the $\mathrm{I} 7$ th. Of course the cases of 1873 and ' 74 would 
not prove anything, as the number taken was so small, although the last two dates are a good deal earlier than I ever remember to have seen a. female, but I consider that the captures of the past season afford strong evidence in favor of the opinion that the males of this species appear at least a week or ten days before the females.

\section{ANNUAL ADDRESS OF THE PRESIDENT OF THE ENTOMOLOGICAL SOCIETY OF ONTARIO.}

\section{To the Members of the Entomological Society of Ontario:}

GENTLEAEN,--In accordance with time-honored usage, it devolves upon your retiring President at the close of another year of the existence of our Society to offer you a few remarks bearing upon the objects and interests of our body, or of Entomology in general.

And first, gentlemen, I desire to congratulate you on the continued prosperity of our Society and the increasing interest felt and manifested in the furtherance of the chief objects we as an organization have in view, viz., the diffusion of practical information in reference to the life history and habits of our insects, so that we may be able to distinguish our friends from our foes, and thus be placed in a position to apply intelligently such remedial measures for the check of insect ravages as experience may suggest to be most practical and effective.

During the past year circumstances have arisen which have brought our Society more prominently before our people than ever before, notably the fact of the accumulation of that grand collection of Canadian insects which we have prepared and forwarded to the Centennial Exhibition in Philadelphia. My esteemed predecessor, in his annual address last year in Toronto, referred to this proposed work, and expressed himself as confidently anticipating the active co-operation of our members in all sections of our country. The result has more than realized our fondest hopes; our members entered most hearily into the work, bringing together a collection of Canadian insects far surpassing anything ever before seen. The comping ont of the cletails of this work was entrusted last year to a special committee, consisting of Messrs. Bethune, Saunders and McMechan, and upon consultation it was resolved to accumulate all 